Agnieszka Barczyk, Renata Nolbrzak

UNIWERSYTET ŁÓDZKI

\title{
Czym się straszy dzieci? Recepcja horroru wśród najmłodszych
}

Pomysł tego tekstu narodził się w naszych głowach po obejrzeniu szóstego odcinka programu Ale madrale!, emitowanego przez polską telewizję publiczną; odcinka poświęconego w znacznej części horrorowi i dziecięcym lękom. W czasie wspomnianego epizodu jeden $z$ bohaterów - kilkuletni chłopiec - wyznał na antenie, że kiedy jest niegrzeczny, rodzice strasza go „szlabanem na kompa”. Ta prosta wypowiedź dobrze wpisuje się w kontekst szeroko pojętych zmian spolecznych, związanych $z$ pojawianiem się nowych technologii. Obecnie - jak zauważa prof. Jarosław Płuciennik - „Śpimy ze smartfonami" ${ }^{\prime}$, co łączy się zarówno $z$ szeregiem zalet, jak i wad. Abstrahujac od waloryzowania, postanawiamy jedynie podkreślić bezdyskusyjną rolę postępu technologicznego w wielu dziedzinach naszego życia, m.in. jego wpływ na ludzkie lęki. Najlepszym dowodem jest nowa fobia współczesnego człowieka, tzw. nomofobia, czyli strach przed brakiem dostępu do telefonu ${ }^{2}$.

\section{O baśniach słów kilka}

Niezależnie od postępu cywilizacyjnego i rozwoju technologii tym, czym wciąż straszy się dzieci, są bajki i baśnie - najstarszy z gatunków literackich. Baśń, przez długie wieki przekazywana droga ustna, została następnie zapisana i poddana literackim modyfikacjom oraz artystycznej obróbce.

1 Nawiazanie do wypowiedzi prof. Jarosława Płuciennika skierowanej podczas wykładu do słuchaczy studiów doktoranckich Wydziału Filologicznego UŁ.

2 Więcej na ten temat można przeczytać w artykule: Nomofobia, czyli uzależnieni od smartfonów, http:/ /dziennikzwiazkowy.com/wydarzenia/nomofobia-czyli-uzaleznieni-od-smartfonow [data dostępu: 12.06.2013]. 
Zainteresowanie dziecka baśniami i bajkami związane jest $z$ potrzeba odgrywania problemów i fantazji. W reakcjach dzieci na bajki można $z$ łatwością zaobserwować potrzebę doznawania różnorodnych uczuć - nie tylko miłości i szczęścia, lecz również strachu, przerażenia, gniewu. Dopiero dzięki doświadczeniu dziecko uczy się panować nad tymi uczuciami i rozumieć, do jakiego stopnia przyczyną ich powstawania są rzeczy, które nigdy nie zdarzają się w rzeczywistości. W tym sensie można mówić, że bajka ma charakter oczyszczający, a jeśli stosować ja umiejętnie, może być środkiem ułatwiającym przystosowanie się dziecka do rzeczywistości, pomagającym mu odróżnić fantazje od prawdy. Jednak niektóre bajki, opowiadane zbyt sugestywnie przez dorosłych, wzbudzaja u dzieci ostre lęki i fobie. Stąd wielu wychowawców opowiada się za ocenzurowaniem ich lub całkowitym usunięciem.

Innego zdania jest Michał Rusinek, który w swoim tekście Kochasz dzieci, to je postrasz ${ }^{3}$ przywołuje Umberto Eco, który twierdzi, że każdy człowiek powinien przejść w dzieciństwie etap fascynacji przemoca, krwia, wojnami, bronią białą oraz palną. Pisarz uważa, że dziecięce zabawy powinny być platonicznie krwawe, by zaszczepić w nas niechęć do tego, co krwawe naprawdę. Wyobrażanie sobie przemocy i destrukcji jest forma zaspokojenia odziedziczonego po przodkach impulsu. Według Umberto Eco, dziecięca wyobraźnia pozwala zaspokoić ten impuls raz na zawsze i przygotować się do przyjęcia innych przesłań. Jest rzeczą ważna - dodaje Eco - by na śmierć i destrukcję patrzeć zawsze jak na kategorie rodem $z$ fantazji, jak na wilka z Czerwonego Kapturka, którego wszyscy nienawidziliśmy, choć przecież nie zrodziła się z tego niechęć do wilków. Michał Rusinek tak się do tego odnosi:

Do tego służy wyobraźnia, ale też literatura... Jako czytelnicy musimy się rozpoznać w literackiej postaci, przeżyć $z$ nią wywołujące krew w żyłach perypetie, by niejako mieć je już za soba, by zostały zaspokojone różne nasze prymitywne impulsy, popędy. [...] Kiedyś wpadła mi w ręce poprawiona, a właściwie ocenzurowana wersja bajki o Czerwonym Kapturku, w której wilk nie pożera babci i Kapturka, tylko chowa je w szafie. Chodziło o to, jak mniemam, by uchronić dzieci przed zgubnym wpływem obcowania z przemoca. Wyszło idiotycznie ${ }^{4}$.

3 M. Rusinek, Kochasz dzieci, to je postrasz, „Książki” 2012, nr 1 (marzec), s. $51-52$.

4 Tamże. 
Powinno się cenzurować bajki czy też nie? Jedni przyjmuja założenie, że ludzie wychowywani „na strachu” nie będa szczęśliwi ani moralni. Inni twierdza, że literatura tego typu wprowadza dzieci w krąg pewnych emocji, pozwala coś przeżyć - a w zasadzie przygotowuje do prawdziwego przeżycia w rzeczywistym świecie. Poglady wśród pedagogów i psychologów na temat wpływu „strasznych” opowieści na dzieci są bardzo zróżnicowane i opis poszczególnych tez oraz wysuwana argumentacja mogłyby stanowić przedmiot oddzielnej analizy.

Pozostawiając ocenę specjalistom od wychowywania, chciałabym przywołać klasyczny przykład literatury grozy dla dzieci - baśnie braci Grimm.

Pierwsze wydanie Baśni dla dzieci i dla domu opublikowano 200 lat temu, od razu wzbudzajac kontrowersje. W stosunku do dzisiejszych wersji znanych bajek, ówczesne były pełne okrucieństwa i zupełnie nieprzeznaczone dla dziecięcego odbiorcy. Można się o tym przekonać, sięgając do wydanego w 2010 r. nowego przekładu $B a-$ śni dla dzieci i dla domu Elizy Pieciul-Karmińskiej ${ }^{5}$. W jednej z baśni ojciec odrąbuje ręce córce, w innej dziewczynka tańczy w rozpalonych do czerwoności trzewiczkach, a w jeszcze innej macocha truje swa pasierbicę. Na przestrzeni lat, ze względu na „poprawność polityczna" baśnie niejednokrotnie były modyfikowane, $z$ początku również przez samych autorów - braci Grimm. Już w drugim wydaniu baśni w roku 1819 zmieniono wiele oryginalnych wątków. Prace redakcyjne, dostosowujące teksty do oczekiwań czytelników, prowadził Wilhelm Grimm.

Kamil Janicki w tekście opublikowanym w grudniu 2012 r. Kazirodztwo, rytualne mordy, kanibalizm. Prawdziwe baśnie braci Grimm $^{6}$ pisze:

Sielankowe historyjki o Jasiu i Małgosi, Tomciu Paluchu czy Czerwonym Kapturku w niczym nie przypominają swoich pierwowzorów: baśni opowiadanych w chłopskich chatach Francji, Niemiec i Anglii kilkaset lat temu. Wtedy w opowieściach dla dzieci krew się lała strumieniami, a trup się ścielił gęsto...

W baśniach nie brakowało także aluzji erotycznych. Przywołajmy choćby fragment baśni o Czerwonym Kapturku:

5 W. i J. Grimm, Baśnie dla dzieci i domu, przekł. E. Pieciul-Karmińska, Poznań 2010.

${ }^{6}$ K. Janicki, Kazirodztwo, rytualne mordy, kanibalizm. Prawdziwe baśnie braci Grimm; http://ciekawostkihistoryczne.pl [data dostępu: 20.09.2013]. 
Wtedy wilk rzekł:

- Rozbierz się i połóż się ze mna.

- Gdzie mam położyć fartuszek?

- Wrzuć go do ognia, nie będzie ci już więcej potrzebny.

Zdejmując ubrania - gorsecik, spódnicę, halkę i pończochy - dziewczynka zadawała to samo pytanie, a wilk za każdym razem odpowiadał:

- Wrzuć to do ognia, nie będzie ci już potrzebne.

W końcu bohaterka kładzie się do łóżka, a wilk ją pożera. W oryginalnej wersji nie ma gajowego, nikt nie ratuje dziewczynki. Bajka nie kończy się happy endem.

Porównania oryginalnych baśni $z$ ich współczesnymi wersjami, dokonywane przez historyków i antropologów, znajdziemy w pracy Roberta Darntona w wydanej w 2012 r. w Polsce książce Wielka masakra kotów i inne epizody francuskiej historii kulturowej ${ }^{7}$.

\section{A dziś?}

Szukając odpowiedzi na pytanie o lęki współczesnego dziecka, przeprowadziłyśmy ankietę na próbie 100 osób. W gronie respondentów znalazło się 55 dziewcząt i 45 chłopców w wieku 8-10 lat. Wszyscy są uczniami Szkoły Podstawowej nr 79 im. Łódzkich Olimpijczyków w Łodzi. Ankieta składała się z 10 pytań (4 zamkniętych i 6 otwartych).

W pierwszej kolejności zależało nam na wyodrębnieniu generatorów strachu. Analiza odpowiedzi respondentów pozwoliła wyróżnić kilka grup, które przedstawia tab. 1.

Tabela 1. Generatory strachu

\begin{tabular}{|c|c|c|c|c|c|}
\hline \multicolumn{3}{|c|}{ Dziewczęta } & \multicolumn{3}{|c|}{ Chłopcy } \\
\hline \multirow{2}{*}{ 兌 } & Ludzie & pani $X(2)^{*}$, tata & \multirow{2}{*}{ 愛 } & Ludzie & $\begin{array}{l}\text { tata - „jak się } \\
\text { wścieknie” (2), } \\
\text { mordercy, brat }\end{array}$ \\
\hline & Zwierzęta & $\begin{array}{l}\text { pająki (24), węże (5), } \\
\text { psy, ślimaki, żaby, } \\
\text { niedźwiedzie, } \\
\text { aligatory, myszy, } \\
\text { bąki, szczury }\end{array}$ & & Zwierzęta & $\begin{array}{l}\text { pająki (5), } \\
\text { tarantule (3), } \\
\text { osy }\end{array}$ \\
\hline
\end{tabular}

7 R. Darnton, Wielka masakra kotów i inne epizody francuskiej historii kulturowej, Warszawa 2012. 


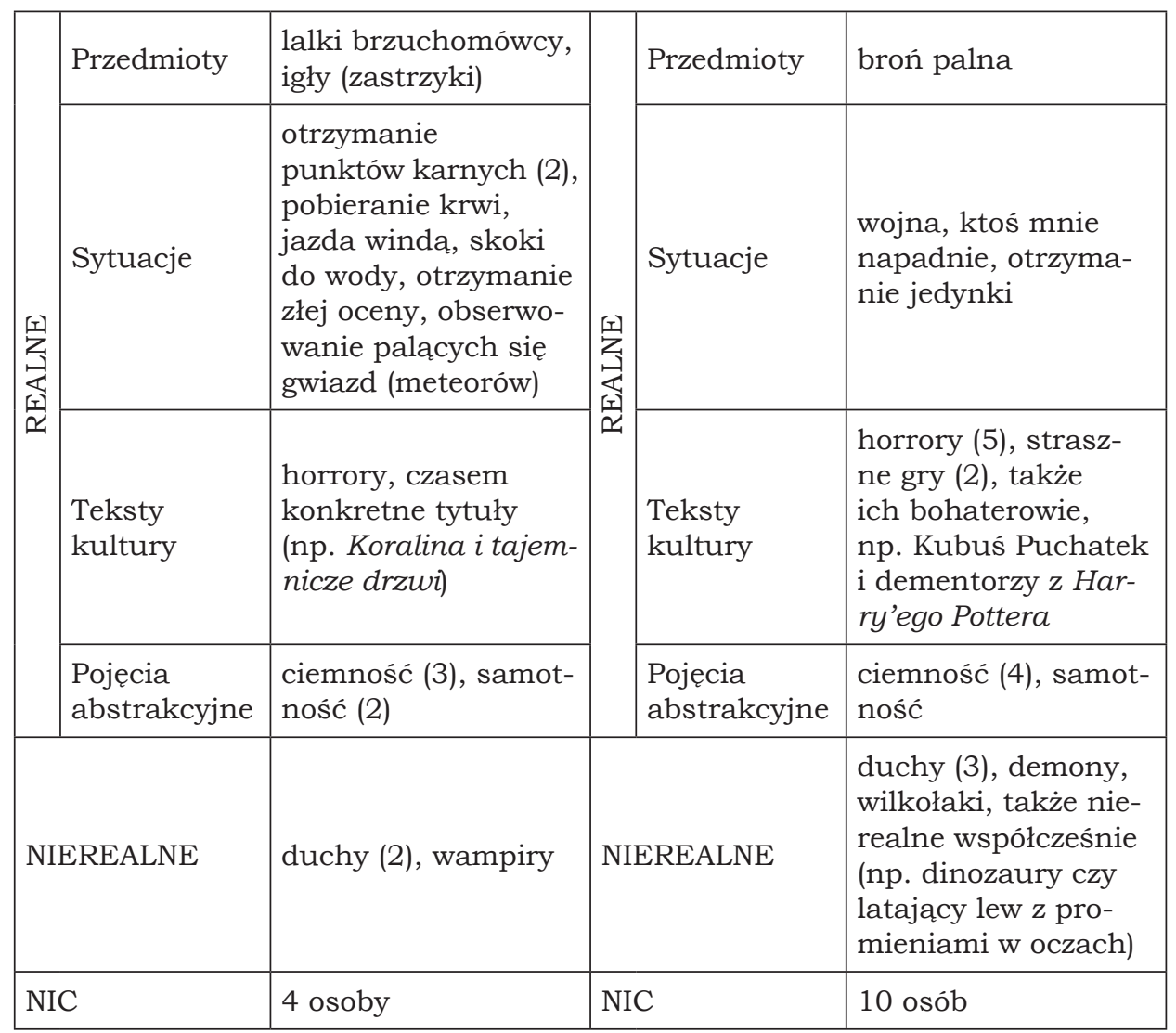

* W nawiasach zaznaczono odpowiedzi, które pojawiały się więcej niż jeden raz.

Źródło: opracowanie własne.

Podstawowa różnica wyłaniająca się $z$ analizy odpowiedzi, jakich udzielały dziewczęta i chłopcy dotyczy ilościowego rozkładu odpowiedzi pomiędzy tym, co realne i namacalne, a tym, co pochodzi ze sfery tekstów kultury oraz wyobrażeń. W wypowiedziach dziewczat zdecydowanie najbardziej rozbudowana była grupa zwierząt, zdominowana przez pająki i węże, dla chłopców większego znaczenia nabierały generatory strachu reprezentujace kategorię tekstów kultury oraz tego, co nierealne. Różnicę te potwierdza zreszta pytanie o to, co jest straszniejsze: duchy czy pajaki? (wykresy 1-3). 


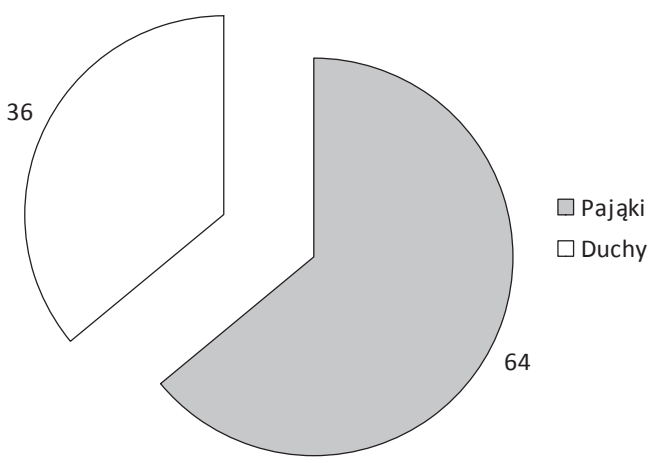

Wykres 1. Co jest straszniejsze: pajaki czy duchy? Źródło: opracowanie własne

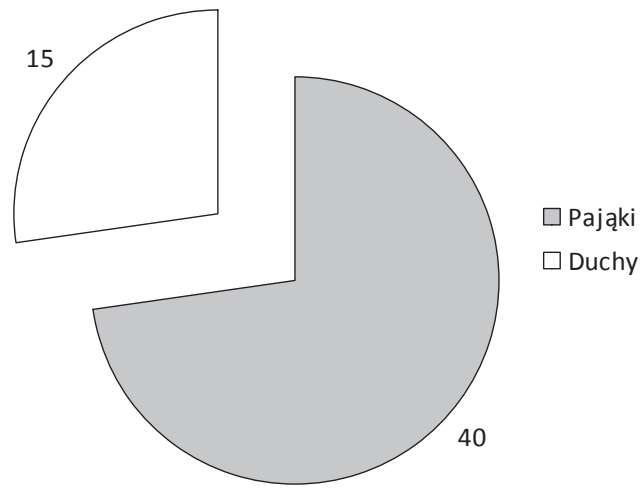

Wykres 2. Rozkład odpowiedzi w grupie dziewcząt Źródło: opracowanie własne
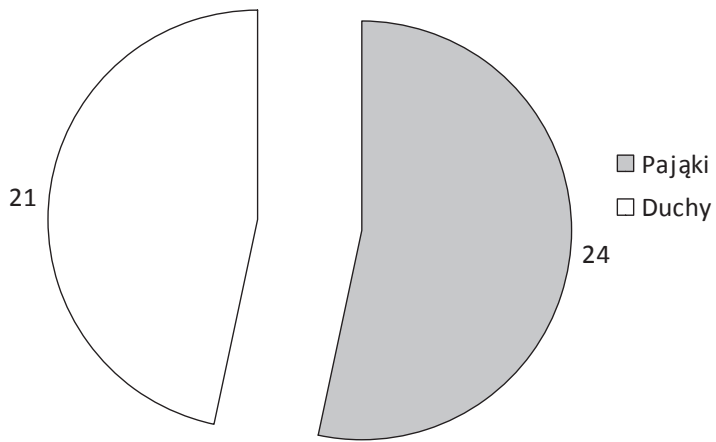

Wykres 3. Rozkład odpowiedzi w grupie chłopców Źródło: opracowanie własne 
Kolejnym krokiem była odpowiedź na pytanie o to, dlaczego dzieci boją się akurat tych elementów (ludzi, zwierząt, tekstów kultury itd.)? Śledzac wypowiedzi respondentów, ustaliłyśmy kilka podstawowych przyczyn strachu:

- cechy, które posiada generator strachu: „jadowite”, „obleśne”, „włochate”, „straszne”, „obślizgłe”, „duże i maja chude nogi”, „mają ostre kły”, „okropny wygląd”, „bo duchy są niewidzialne”, „bo krzyczy";

- konsekwencje dla jednostki: „może zabić”, „one zjadaja dzieci”, „zła ocena obniży mi średnia”;

- konsekwencje dla szerszej grupy: „boję się takiej gwiazdy, bo jak spadnie, to ziemia się spali”, „ponieważ ginie tam dużo ludzi”;

- poczucie dyskomfortu: „boję się pobierania krwi, ponieważ to nie jest przyjemne uczucie”, „bo mnie obrzydzaja”, „gdy jest ciemno, nie widzę, co się wkoło mnie dzieje”, „kiedy jestem sama, nikt mi nie pomoże";

- własne doświadczenia: „bo na mnie nawrzeszczała”, „jak miałam pięć lat, miałam dużo ich i widziałam, jak pająk pożerał muchę”, „jak miałam pięć lat, widziałam okropną rzecz”, „boję się pająków, ponieważ był u mnie w domu”, „bo pies mnie rok temu ugryzł”, „mam sny $z$ wężami”, „bo raz widziałem, jak osie $z$ żądła kapał jad";

- brak racjonalnego wytłumaczenia: „nie wiem, po prostu już tak mam”, „bo się boję”, „nie wiem”.

Tak zarysowane tło, które stanowi swego rodzaju mapę lęków oraz ich przyczyn, stało się punktem wyjścia do pytań zasadniczych dla niniejszego opracowania, czyli związanych ze strasznymi filmami (wykres 4).

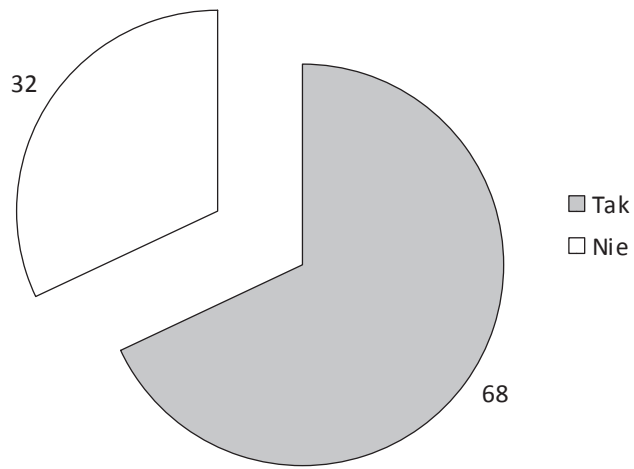

Wykres 4. Oglądalność strasznych filmów wśród respondentów Źródło: opracowanie własne 
Zdecydowana większość respondentów (68\%) ogląda straszne filmy, lecz nie zawsze potrafi podać przynajmniej jeden konkretny tytuł (13\% ankietowanych w ogóle nie pamiętało tytułu). Wskazane przez respondentów tytuły prezentuje tab. 2 .

Tabela 2. Tytuły strasznych filmów

\begin{tabular}{|l|l|}
\hline \multicolumn{1}{|c|}{ Dziewczęta } & \multicolumn{1}{c|}{ Chłopcy } \\
\hline Harry Potter (4) & Piła (8) \\
Zmierzch (4) & Park Jurajski (2) \\
Monster High (2) & Doktor House, Fantomas, Halloween \\
Oszukać przeznaczenie (2) & - powrót, Harry Potter, Hobbit, Iron \\
Anna German, Czarnobyl. Reaktor & Man, Komisarz Alex, Krzyk, Malanow- \\
strachu, Doktor House, Hobbit, Iron & ski i partnerzy, Megawą̇, Noc żywych \\
Man, Kill Bill, Lekarze, Moja niania jest & trupów, Nawiedzony dom, Obcy, \\
wampirem, Park Jurajski, Piła, Statek,, & Obcy kontra Predator, Ojciec Mateusz, \\
Straszny film... & Oszukać przeznaczenie, Poszuki- \\
& wacze duchów, Ring, Straszny film, \\
& Szczęi, Władca pierścieni, Wojna \\
& światów... \\
\hline
\end{tabular}

Źródło: opracowanie własne.

Analiza sporządzonych przez ankietowanych opisów przywoływanych filmów pozwoliła stworzyć swego rodzaju katalog motywów wywołujacych strach:

- postaci: wampiry, wilkołaki, zombie, żywe trupy, duchy, kosmici, demony, czarodzieje, mordercy, „facet w masce”;

- stwory-zwierzęta: dinozaury, pajaki, rekiny;

- miejsca: nawiedzony dom;

- przedmioty: piła, pistolety;

- ciało: krew, wnętrzności, wydłubane oczy, chirurgia, śmierć;

- inne: wybuchy, zła magia, zemsta, zabijanie, porywanie dzieci.

Należy zwrócić uwagę, że zdecydowana większość ankietowanych ogląda straszne filmy za zgodą swoich rodziców (tylko nieliczne wyjątki nie maja zgody). Co ciekawe, niektóre dzieci - nawet posiadając tę zgodę - rezygnują $z$ oglądania takich tekstów kultury (wykresy 5-8).

Ostatnim celem, jaki sobie wytyczyłyśmy, było zbadanie wiedzy respondentów na temat horrorów. W tej części badania zadałyśmy dwa pytania: o definicję horroru oraz motywacje, jakie kieruja odbiorca, który sięga po tytuły reprezentujące ten gatunek filmów. 


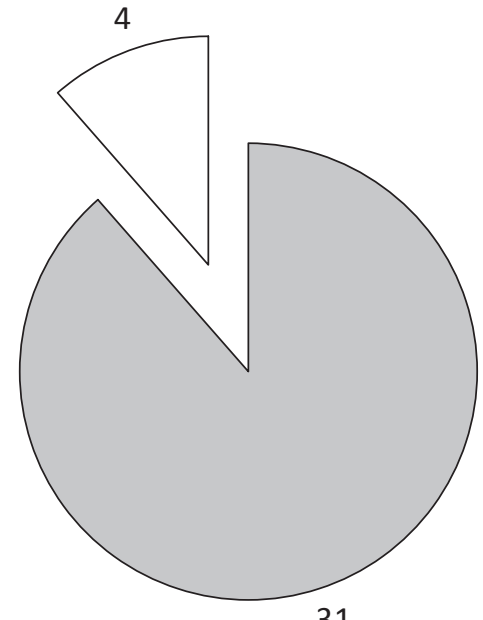

a)

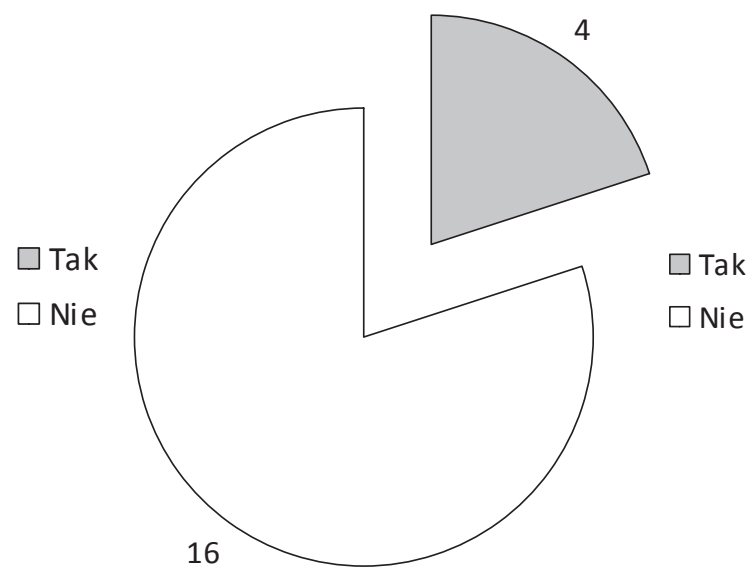

b)

Wykres 5 i 6. Zgoda rodziców dla dziewcząt: a) oglądających straszne filmy, b) nieoglądajacych takich filmów Źródło: opracowanie własne

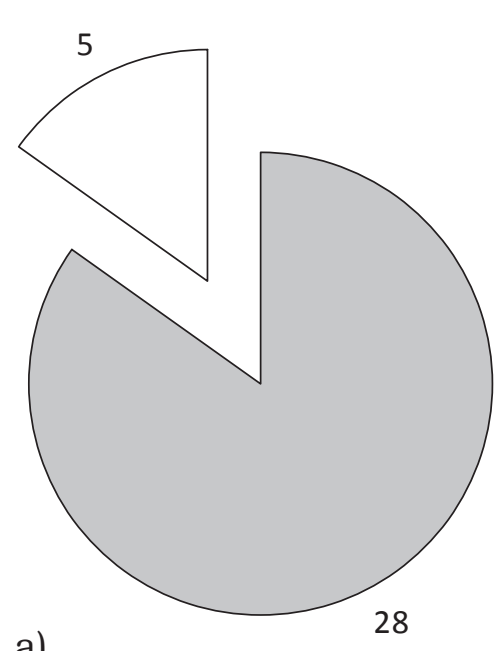

a)

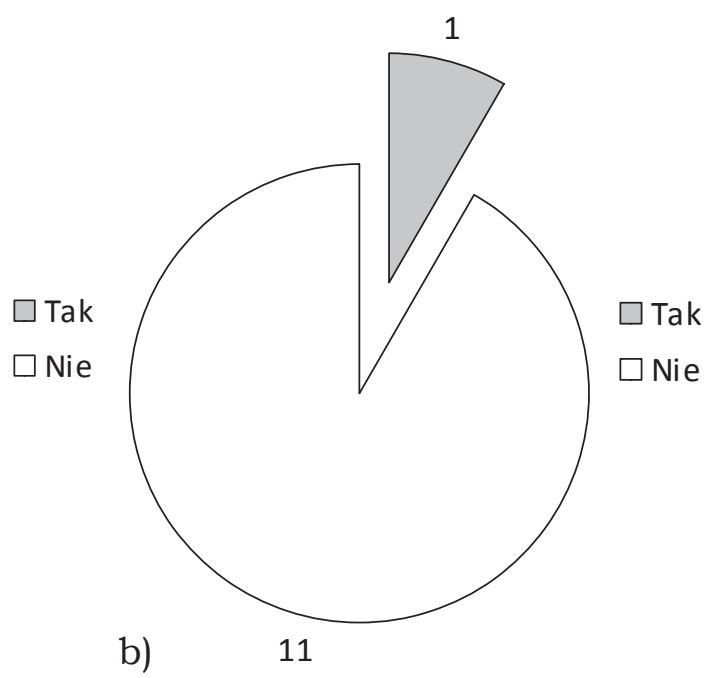

Wykres 7 i 8. Zgoda rodziców dla chłopców: a) oglądających straszne filmy, b) nieoglądających takich filmów Źródło: opracowanie własne 
Definiujac horror, ankietowani zawracali uwagę na różne aspekty. Efektem analizy wykorzystywanych przez dzieci kierunków definiowania jest poniższe zestawienie:

- co to? film;

- jakie ma cechy? strach + film = „straszny film” (58 osób!), inne kombinacje: „krwawy film”, „film grozy”, „fajny film”;

- o czym? "Straszny film, w którym widziałam, jak chłopakowi oderwali głowę", „film, w którym jest krew, zabijanki i takie tam”, „film o złym zakończeniu, w którym często ożywaja przedmioty, a ludzie się zabijaja”, „Film, w którym są niemiłe rzeczy i dużo krwi”;

- jaki odbiorca? „film dla dorosłych”, „program nie dla dzieci”;

- jaka funkcja? „film, który ma nas wystraszyć”;

- tylko film? „coś strasznego”;

- idem per idem: „to horror”;

- nie wiem - 6 osób.

Analiza odpowiedzi na pytanie o to, dlaczego oglądamy horrory, pozwoliła wyróżnić trzy podstawowe grupy: cechy przekazu, motywacje, które kierują odbiorca oraz inne (czyli po prostu odpowiedź „nie wiem”, która padła 18 razy) (wykresy 9-11).

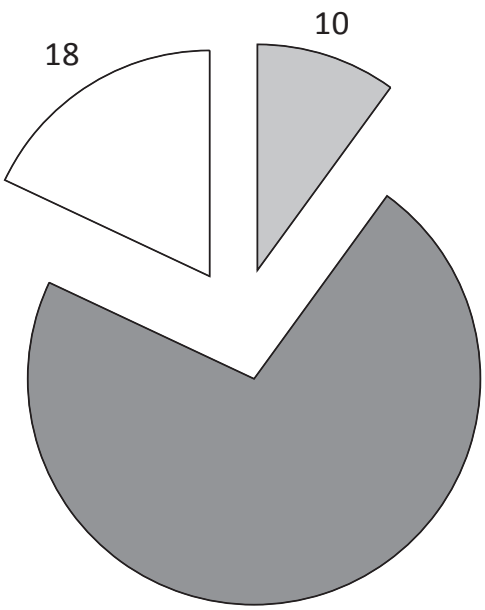

72
Cechy przekazu

$\square$ Oczekiwania odbiorców

$\square$ Inne

Wykres 9. Dlaczego oglądamy horrory? Źródło: opracowanie własne 


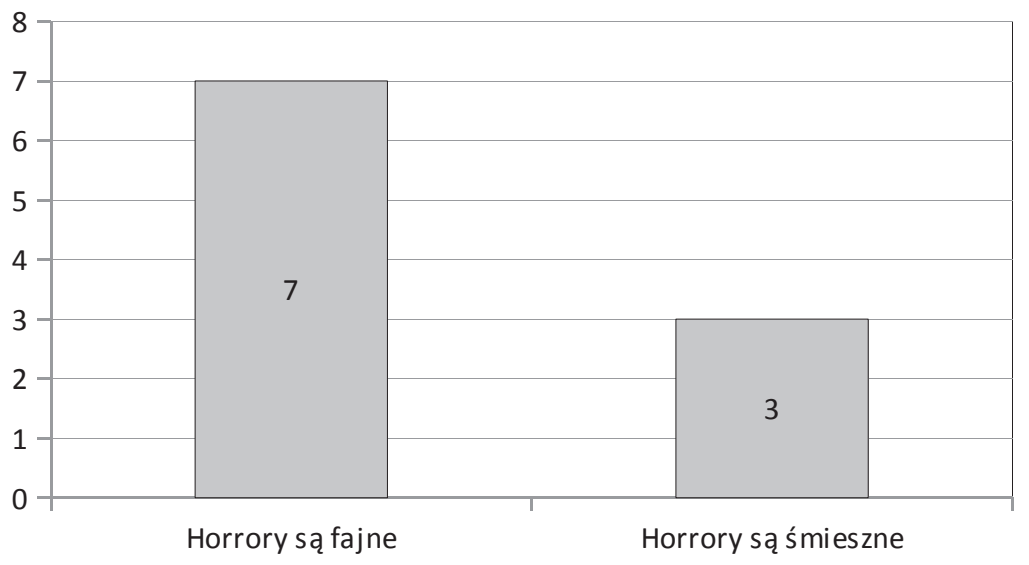

Wykres 10. Cechy przekazu

Źródło: opracowanie własne

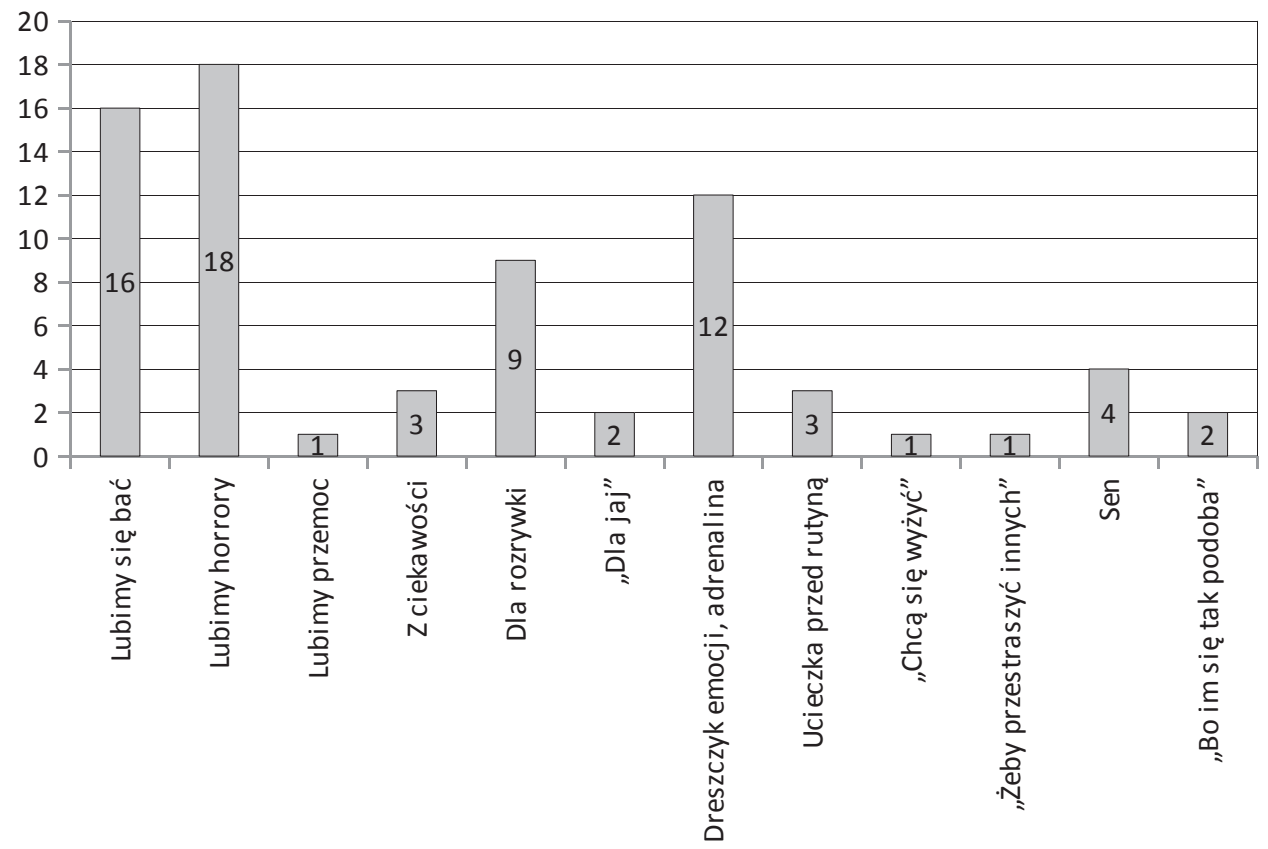

Wykres 11. Oczekiwania odbiorcy ${ }^{8}$

Źródło: opracowanie własne

8 Grupa najbardziej zróżnicowanych motywacji została zbiorczo określona jako „Sen”. $Z$ jednej strony dorośli oglądają horrory, „Ponieważ chca mieć miło wyspane noce”, $z$ drugiej: „Chca mieć straszne sny”; $z$ jednej: „Bo horrory usypiaja dorosłych”, z drugiej: „Żeby nie zasnąć”. 


\section{Uwagi końcowe}

Uczucie lęku, strachu, obawy przed tajemniczym i nieznanym to naturalne stany, towarzyszace człowiekowi od najmłodszych lat. Jednym $z$ istotnych ich generatorów jest kultura, a właściwie teksty, które w jej obrębie powstają. Mroczne fabuły, budzące grozę światy przedstawione lub nieludzcy bohaterowie, zarówno ze świata literatury, jak i filmu, mogą odcisnąć wyraźne piętno na psychice młodego odbiorcy. Odwieczne pytania: straszyć dzieci czy chronić je przed takimi przekazami, cenzurować bajki czy nie, pozwalać na oglądanie strasznych filmów czy kategorycznie zabraniać - pozostawiamy bez jednoznacznej odpowiedzi, gdyż nie taki był cel tego tekstu. Zależało nam przede wszystkim na rozrysowaniu „mapy” lęków współczesnego dziecka i podkreśleniu, jak dużą rolę w jego wychowaniu i socjalizacji odgrywaja obecnie nowe technologie. Pojawienie się nowego środka zawsze łączy się z szeregiem zalet, ale również wad, grunt więc to zachować umiar. Nie poddajemy ostrej krytyce tego, że dzieci jeszcze przed pójściem do szkoły opanowuja umiejętność posługiwania się komputerem czy tabletem, które „przenosza” je do wirtualnego świata - nieograniczonego i niczym nieskrępowanego oceanu przekazów. Zwracamy jednak uwagę, że szczególnie rodzicom powinno dziś zależeć, by rozwój IQ szedł w parze $z$ rozwojem $\mathrm{EQ}$, by w ankietach dzieci nie pojawiała się już więcej samotność.

\section{Bibliografia}

Danton R., Wielka masakra kotów i inne epizody francuskiej historii kulturowej, Warszawa 2012.

Grimm W. i J., Baśnie dla dzieci i domu, przekł. E. Pieciul-Karmińska, Poznań 2010. Janicki K., Kazirodztwo, rytualne mordy, kanibalizm. Prawdziwe baśnie braci Grimm; http://ciekawostkihistoryczne.pl [data dostępu: 20.09.2013].

Nomofobia, czyli uzależnieni od smartfonów, http://dziennikzwiazkowy.com/wydarzenia/nomofobia-czyli-uzaleznieni-od-smartfonow [data dostępu: 12.06.2013]. Rusinek M., Kochasz dzieci, to je postrasz, „Książki” 2012, nr 1 (marzec).

\section{Abstract}

In the sixth episode of the program Ale madrale! (TVP) one child - a young boy - says that when he is naughty, parents threaten him: "We will take your computer". This simple statement fits well into the context of social changes associated with the introduction of new technologies. With them also change our fears, including fears of a child. The article is a journey into the world of children's fears - first we go to the realm of children's literature and its dark secrets, then visit one of the primary schools in Lodz, where we did our research.

Key words: horror, fear, children, literature. 